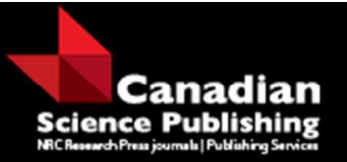

Canadian Journal of Forest Research Revue canadienne de recherche forestière

\title{
Surface soil organic carbon in temperate and sub-tropical oriental oak stands of East China
}

\begin{tabular}{|r|l|}
\hline Journal: & Canadian Journal of Forest Research \\
\hline Manuscript ID & cjfr-2015-0324.R2 \\
\hline Manuscript Type: & Article \\
\hline Date Submitted by the Author: & 01-Feb-2016 \\
\hline Complete List of Authors: & $\begin{array}{l}\text { Yu, Wenjuan; Shanghai Jiao Tong University, School of Agriculture and } \\
\text { Biology } \\
\text { Fahey, Timothy; Cornell University, Natural Resources } \\
\text { Kang, Hongzhang; School of Agriculture and Biology, Shanghai Jiao Tong } \\
\text { University } \\
\text { Zhou, Pisheng; Shanghai Jiao Tong University, School of Agriculture and } \\
\text { Biology }\end{array}$ \\
\hline Keyword: & $\begin{array}{l}\text { soil organic matter, CPMAS < sup }>13</ \text { sup }>C \text { C NMR, } \delta<\text { sup }>13</ \text { sup }>C, \\
\delta<\text { sup }>15</ \text { sup }>\text { N, soil properties }\end{array}$ \\
\hline &
\end{tabular}


1 Title: Surface soil organic carbon in temperate and sub-tropical oriental oak stands

2 of East China

3 Authors: Wenjuan Yu, ${ }^{\underline{a}}$ Timothy J. Fahey, ${ }^{\underline{b}}$ Hongzhang Kang, ${ }^{a}$ Pisheng Zhou ${ }^{\underline{a}}$

$4 \quad{ }^{a}$ School of Agriculture and Biology, Shanghai Jiao Tong University, 800 Dongchuan

5 Rd., Shanghai 200240, China, wjyu@sjtu.edu.cn; kanghz@sjtu.edu.cn;

6 pszhou@sjtu.edu.cn

$7 \quad{ }^{b}$ Department of Natural Resources, Cornell University, G16 Fernow Hall, Ithaca

8 14853-3001, NY, USA, tif5@cornell.edu

9 Corresponding author: Hongzhang Kang. School of Agriculture and Biology, Shanghai

10 Jiao Tong University, 800 Dongchuan Rd., Shanghai 200240, China. Tel. \& Fax: +86 21

11 34206605. E-mail: kanghz@sjtu.edu.cn 


\section{Abstract}

Forest ecosystems contain large amounts of soil organic carbon (SOC) which is a major component of biogeochemical cycles that may be sensitive to environmental change. We used a combination of nuclear magnetic resonance (NMR) spectroscopy and elemental and isotopic composition to examine the influence of soil properties and climatic factors on the quantity and degree of decomposition of SOC for organic and surface mineral horizons in seven oriental oak (Quercus variabilis) forest sites arranged across a $11^{\circ}$ latitudinal gradient in East China. Lacking Oa horizons, the two southernmost sites contained lower amounts of SOC in the forest floor horizon but otherwise latitudinal trends were not consistent. The SOC stock in the $0-10 \mathrm{~cm}$ mineral horizon exhibited no clear trend along the gradient and had a negative association with clay + silt content. Based on higher alkyl/O-alkyl (A/O) ratio and alkyl/methoxyl $(\mathrm{A} / \mathrm{M})$ ratio, the $\mathrm{SOC}$ at the $0-10 \mathrm{~cm}$ depth appeared to be relatively more decomposed in three of the four southern sub-tropical sites. However, the degree of SOC degradation also decreased strongly with increasing soil $\mathrm{pH}\left(\mathrm{R}^{2}=0.90\right.$, $P=0.001)$. Soil OC exhibited increases in $\delta^{13} \mathrm{C}, \delta^{15} \mathrm{~N}$ and decreases in $\mathrm{C} / \mathrm{N}$ with depth for all the seven sites, indicating an increase in its extent of decomposition. Our analysis indicated that the $A / M$ ratio from NMR provided the best indication of the extent of SOC degradation along the latitudinal transect whereas the elemental and isotopic composition better reflected patterns with soil depth.

\section{Keywords}

Soil organic matter, soil properties, climate, CP-MAS ${ }^{13} \mathrm{CNMR}, \delta^{13} \mathrm{C}, \delta^{15} \mathrm{~N}$

\section{Introduction}


Forest ecosystems in the Northern Hemisphere cover $2 \times 10^{9}$ ha and contain large amounts of carbon (C) (390 Pg), representing a huge reservoir of $\mathrm{C}$ on a global basis, mainly in the form of soil organic carbon (SOC, 260 Pg) (Goodale et al. 2002). Eswaran et al. (1993) estimated that $1576 \mathrm{Pg}$ of OC is stored in soils globally, with $506 \mathrm{Pg}(32 \%)$ of this in soils of the tropics, and $40 \%$ of the $\mathrm{C}$ in soils of the tropics is in forest soils. Any change in the size and the turnover rate of soil $\mathrm{C}$ pools may potentially alter the atmospheric $\mathrm{CO}_{2}$ concentration and the global climate (von Lützow et al. 2006).

Forest soil C storage is broadly associated with climate, management and disturbance history, tree species composition, microbial community composition and activity and soil physical properties (Johnsen et al. 2013). For example, climate influences the accumulation and stabilization of soil $\mathrm{C}$ pools as the biological activity that affects $C$ turnover is temperature dependent (Pendall et al. 2004; Whitby and Madritch 2013). Tree species composition also has an important effect on the quantity and quality of SOC pools (Laganiere et al. 2013; Wang et al. 2013), e.g., by influencing soil microclimatic conditions (Hobbie et al. 2006), and by producing leaf

51 and root litter in variable amounts and quality (Berg 2000). Xu et al. (2016)

52 highlighted that clay content was the most important variable in regulating 53 decomposition of SOC at a large scale (mean annual temperature ranging from -15 to $5426^{\circ} \mathrm{C}$ ). Despite its pivotal role, our understanding of forest SOC and its controlling 55 factors remains incomplete.

56 A variety of methods have been used to characterize the complex chemistry of

57 SOC. Solid-state ${ }^{13} \mathrm{C}$ Nuclear Magnetic Resonance with cross-polarization and magic 
58 angle spinning (CP-MAS ${ }^{13} \mathrm{C}$ NMR) provides a first approximation of the relative

59 abundance of organic C functional groups (Baldock et al. 1997; Clemente et al. 2012).

60 The relative distributions of these broad C categories in SOC vary with decay (Yuste

61 et al. 2012); for example, as the extent of degradation increases, the alkyl C spectral

62 region increases concomitantly with the decrease in the O-alkyl C spectral region,

63 and thus the alkyl/O-alkyl $(\mathrm{A} / \mathrm{O})$ ratio has been widely used to indicate the degree of

64 organic matter decomposition (Baldock et al. 1997). Another indicator of the extent

65 of SOC decomposition is the stable isotopic composition $\left(\delta^{13} \mathrm{C}\right)$ because reaction

66 rates are slower for heavy than for lighter isotopes, enriching the remaining SOC

67 with heavy isotopes (Guillaume et al. 2015). Indicating increases in stabilized SOC at

68 greater soil depths, notably, both the $\mathrm{A} / \mathrm{O}$ ratio and the $\delta^{13} \mathrm{C}$ of SOC increase with

69 depth in many soil profiles (Quideau et al. 2000; Garten Jr 2006; Schneckenberger

70 and Kuzyakov 2007). Using these methods researchers have also observed that SOC

71 may be less decomposed at higher latitudes at least in sub-arctic zones (Norris et al.

72 2011; Sjogersten et al. 2003). To our knowledge no such studies have been

73 conducted comparing temperate and sub-tropical climatic zones.

74 In the present study, samples of the forest floor layers (Oe and Oa) as well as

75 surface mineral soil horizons $(0-2,2-5$, and $5-10 \mathrm{~cm})$ were taken from seven oriental

76 oak forest sites in East China, three in the warm temperate climatic zone and four in

77 the sub-tropical zone, and assessed by CP-MAS ${ }^{13} \mathrm{C} N \mathrm{NR}$, elemental and isotopic

78 analyses. Oriental oak (Quercus variabilis) is a common deciduous broadleaf tree

79 species in East Asia $\left(24^{\circ}\right.$ to $42^{\circ} \mathrm{N}$ and $96^{\circ}$ to $\left.140^{\circ} \mathrm{E}\right)$. Its distribution encompasses a

80 wide range of annual temperature and precipitation (Kang et al. 2011), providing a 
81 natural climatic gradient for studying SOC dynamics across two zones with control 82 for tree species composition. We focused on the organic and surface mineral soil 83 horizons which contain large amounts of carbon that may be sensitive to 84 environmental change (Du et al. 2014; Liski et al. 1999). The aims of this study were 85 (1) to investigate soil OC stock and concentration along the climatic gradient; (2) to 86 investigate the degree of SOC decomposition, as indicated by CP-MAS ${ }^{13} \mathrm{C}$ NMR and $87 \delta^{13} \mathrm{C}$ and $\delta^{15} \mathrm{~N}$, along both the latitudinal and depth gradients; and (3) to examine the 88 role of soil properties and climatic factors determining SOC quantity and degree of 89 decomposition along the gradient.

\section{2. Materials and methods}

91 2.1. Site descriptions

In July 2014, seven oriental oak stands were sampled across a large latitudinal range spanning $1500 \mathrm{~km}$ in East China, extending from Beijing $\left(40.25^{\circ} \mathrm{N}, 117.12^{\circ} \mathrm{E}\right)$ to

94 Jiangxi $\left(29.09^{\circ} \mathrm{N}, 115.62^{\circ} \mathrm{E}\right)$ (Fig. 1). Three sites (PG, HYS and BA) are located in the 95 warm temperate zone based on the conventional boundary at $35^{\circ} \mathrm{N}$ latitude, while 96 four sites (HZY, XY, HS, YS) are in the subtropical zone. All the sites are natural, 97 second-growth, monospecific oriental oak stands which have not been disturbed by 98 direct human activities and wildfires for at least the last five decades. Among the 99 seven sites, only Site HZY had an important herbaceous layer. Soils in the sites 100 encompass three soil orders (USDA Soil Taxonomy); entisols at three sites (PG, HYS, $101 \mathrm{BA})$, inceptisols at two sites (HZY, XY) and ultisols at the most southerly sites (HS, YS). 102 Climatic conditions of these sites change from cooler and drier in the north (mean 103 annual temperature (MAT) from $11.1^{\circ} \mathrm{C}$, and mean annual precipitation (MAP) from 
$104492 \mathrm{~mm}$ ) to warm and wet in the south (MAT $16.9^{\circ} \mathrm{C}$ and MAP $1759 \mathrm{~mm}$ ) (Table 1).

105 Combining MAP and MAT, annual actual evapotranspiration (AET) was estimated

106 using formula (1) (Ding 2013):

107

(1) $A E T=M A P \div \sqrt{\left[0.9+\left(M A P \div E_{0}\right)^{2}\right]} ; E_{0}=300+25 \times M A T+0.5 \times M A T^{3}$

$A E T$ : annual actual evapotranspiration, $\mathrm{mm} ; \mathrm{MAT}$ : mean annual temperature, ${ }^{\circ} \mathrm{C}$;

MAP: mean annual precipitation, $\mathrm{mm} ; E_{0}$ : maximum annual potential of

110 evapotranspiration with sufficient soil water, $\mathrm{mm}$.

\section{$111 \quad$ 2.2. Field Sampling}

112 At each site, forest structure was characterized in a $20 \mathrm{~m} \times 20 \mathrm{~m}$ plot positioned

113 at mid-slope in the study area and canopy height and stem diameter at breast height

114 were measured for each tree (Table 1). Five parallel transects were established into

115 each site with $10 \mathrm{~m}$ spacing between them and with 10 sampling points on each

116 transect at $5 \mathrm{~m}$ spacing (i.e. $50 \times 50 \mathrm{~m}$ grid). The forest floor horizons (Oe and Oa)

117 were collected with hand spades in a circle $13 \mathrm{~cm}$ in diameter to the top of the

118 mineral soil; the boundary between forest floor and mineral soil was usually distinct,

119 marked by high stoniness and by color and texture. Mineral soil samples were

120 collected with a $2.5-\mathrm{cm}$ corer at $0-2,2-5$, and 5-10 cm depths. For each of the five

121 transects, the samples from the 10 points were composited by horizons. Oa horizons

122 were not observed at the two southernmost sites, HS and YS.

123 Ten additional $2.5-\mathrm{cm}$ diameter soil cores of the whole $0-10 \mathrm{~cm}$ mineral horizon

124 were collected on each transect, and composited by transect for measuring soil

$125 \mathrm{pH}, \% \mathrm{C}, \% \mathrm{~N}$ and texture. Fifteen soil cores (three per transect) were excavated to 10

$126 \mathrm{~cm}$ depth using a bulk density corer. Soil samples were placed in polyethylene bags, 
127 stored on ice and transferred to the laboratory within $24 \mathrm{~h}$. Mineral soils were sieved

$128(2 \mathrm{~mm})$, and mass of the fine and coarse fractions was measured. The Oe and $\mathrm{Oa}$

129 horizons were chopped into small pieces $(<5 \mathrm{~mm})$.

$130 \quad$ 2.3. Soil physico-chemistry

131 Using the $0-10 \mathrm{~cm}$ bulk mineral soil, soil $\mathrm{pH}$ was measured at a soil-to-water

132 ratio of $1: 2.5(\mathrm{~m} / \mathrm{v})$; soil particles were classified into silt, clay and sand using the

133 Bouyoucos hydrometer method (Elliott et al. 1999). Bulk density of the $0-10 \mathrm{~cm}$

134 mineral soil was calculated by dividing the dry weight (dried at $105^{\circ} \mathrm{C}$ until constant

135 weight) by the soil core volume (corrected with the volume of stones (>2 $\mathrm{mm})$ ).

136 Forest floor $\mathrm{C}$ stock was calculated as the product of dry mass and C concentration,

137 while $0-10 \mathrm{~cm}$ mineral soil $\mathrm{C}$ stock was estimated using the concentration data and

138 bulk density measures, and both values were scaled to $\mathrm{kg} \mathrm{m}^{-2}$. Both carbon stock and

139 carbon concentration were used to indicate SOC quantity.

$140 \quad$ 2.4. NMR analysis

141 Two of the five replicates for each depth and site were used for NMR analysis.

142 Prior to NMR analysis, each of the 42 mineral soil samples ( 3 depths $\times 2$ replicates $\times$

1437 sites) were treated with hydrofluoric acid (HF) to concentrate the organic matter

144 and remove paramagnetic minerals (Simpson and Simpson 2012). About $5 \mathrm{~g}$ of the

145 sample was shaken with $30 \mathrm{~mL} 10 \% \mathrm{HF}$ for $2 \mathrm{~h}$. After centrifugation for $10 \mathrm{~min}$, the

146 supernatant was removed. The procedure was repeated five times. The remaining

147 sediment was washed five times with $30 \mathrm{~mL}$ deionized water to remove residual $\mathrm{HF}$

148 before freeze drying. Using two parallel samples, the CP-MAS ${ }^{13} \mathrm{C} N M R$ spectra for 149 each mineral horizon at each site were acquired twice on a Bruker Avance $400 \mathrm{MHz}$ 
150 NMR spectrometer, equipped with a $4 \mathrm{~mm}$ broadband CP-MAS probe.

151 Approximately $100 \mathrm{mg}$ of sample was packed into a $4 \mathrm{~mm}$ zirconium rotor with a

152 Kel-F cap. The acquisition parameters were as follows: spectral frequency of 100.613

$153 \mathrm{MHz}$ for ${ }^{13} \mathrm{C}$ and $400.13 \mathrm{MHz}$ for ${ }^{1} \mathrm{H}$, spinning rate of $5 \mathrm{kHz}$, ramp-CP contact time of

1541.5 millisecond, 1 s recycle delay, 17128-100967 scans per sample and exponential

155 line broadening of $50 \mathrm{~Hz}$. Glycine was used as an external standard to calibrate the 156 chemical shifts.

157 After correcting the spinning sidebands of carboxyl carbon, the spectra were 158 integrated using Topspin V. 2.1 and assigned based on Mathers et al. (2007). Eight 159 structural regions were integrated: alkyl carbon (0-45 ppm), N-alkyl/methoxyl carbon 160 (45-60 ppm), carbohydrate carbon (60-90 ppm), Di-O-alkyl carbon (90-110 ppm), aryl 161 carbon (110-145 ppm), O-aryl carbon (145-165 ppm), carboxyl carbon (165-190 ppm), 162 and ketone carbon (190-210 ppm). The alkyl region (0-45 ppm) contains carbon in 163 compounds such as lipids, cutin and suberin. The O-alkyl C region (45-110 ppm) 164 typically corresponds to more easily degraded OM constituents, such as those found 165 in carbohydrates (Supplementary Fig. S1)(Simpson and Simpson 2012). The 166 Alkyl/O-alkyl (A/O) ratio, which usually increases with progressive degradation, was 167 calculated by dividing the area of the alkyl region $(0-45 \mathrm{ppm})$ by the area of the 168 O-alkyl (45-110 ppm) region (Simpson et al. 2008). The alkyl/methoxyl (A/M) ratio 169 also was calculated based on the area of the alkyl region (0-45 ppm) and the $170 \mathrm{~N}$-alkyl/methoxyl region (45-60 ppm). Both the $\mathrm{A} / \mathrm{O}$ and $\mathrm{A} / \mathrm{M}$ ratios were used to 171 indicate the degree of SOC decomposition.

172 2.5. Elemental and isotopic analyses 
174 were dried at $65^{\circ} \mathrm{C}$ until constant weight, before isotopic analysis. The isotopic 175 composition, total carbon and nitrogen of these samples were measured on a Vario

176 EL III Elemental Analyzer coupled to an Isotopic Ratio Mass Spectrometer (Elementar 177 Analysensysteme $\mathrm{GmbH}$, Germany). Elemental results were converted to an 178 oven-dry weight basis. Isotopic results were expressed in the $\delta$-notation, as the \%o 179 variation from the standard reference material, Pee Dee Belemnite (PDB) for C and 180 atmospheric $\mathrm{N}_{2}$ for $\mathrm{N}$.

181 2.6. Statistics

182 Statistical tests were performed using the SPSS 19.0 software (SPSS Inc., 183 Chicago, IL, USA). While the other data were calculated as arithmetic means of five 184 replicates with standard errors, NMR data were calculated as arithmetic means of 185 two replicates. To perform the following statistical methods, NMR compositions at 186 the $0-10 \mathrm{~cm}$ depth were calculated by summing the weighted values of $0-2,2-5$, and $187 \quad 5-10 \mathrm{~cm}$ depths (i.e. multiplied by $0.2,0.3$, and 0.5 , respectively).

188 A general linear model was applied to evaluate differences between climatic 189 zones of carbon stock and the various indexes of degree of SOC decomposition. For 190 0-10 cm mineral horizon, Pearson correlations were used to evaluate the 191 inter-relationships among the soil and climate variables. Stepwise multiple 192 regression analyses were conducted to evaluate the effects of soil and climate 193 factors on SOC concentration and degree of degradation, where MAP, MAT, and AET 194 were included as climatic variables, while clay + silt content and $\mathrm{pH}$ were included as 195 soil properties. 
196

197

\section{Results}

\subsection{Soil OC concentration and stock}

Forest floor organic $C$ stock differed significantly between zones $(P<0.001$, Supplementary Table S1). At the most southerly sites (HS and YS), where Oa horizons were lacking, forest floor OC stock was particularly low $\left(0.17\right.$ and $0.28 \mathrm{~kg} \mathrm{~m}^{-2}$, respectively) and low forest floor OC stock was also observed at a third sub-tropical site (site HZY) that had a thin Oa horizon (Fig. 2). However, one of the sub-tropical sites (site XY) had comparatively well-developed forest floor horizons, similar to the temperate zone sites. The $0-10 \mathrm{~cm}$ mineral $\mathrm{SOC}$ stock exhibited no significant difference between climatic zones $(P=0.359)$, and it did not show any clear trend with latitude (Fig. 2). Based on stepwise regression analysis the only soil or climatic factor that had a significant effect on mineral soil OC concentration was silt + clay content: \% C decreased with increasing silt + clay across the seven sites $\left(R^{2}=0.66, P\right.$ $=0.026$, Table 2 ) .

\subsection{Soil organic C: NMR analysis}

For the $0-10 \mathrm{~cm}$ mineral soil, the percentage of signal intensity attributable to alkyl $C$ was significantly lower $(P=0.021)$ in the northern sites than in the southern sites (Table 3, Supplementary Table S1). The percentage of alkyl C was significantly correlated with both $\mathrm{pH}$ and AET (Table 4). The relative contribution of methoxyl $\mathrm{C}$ to total signal intensity also was significantly different between zones $(P=0.038$, Supplementary Table S1) and generally higher in the northern sites than in the southern sites (Table 3); it was strongly correlated with $\mathrm{pH}$, and significantly correlated with MAP and AET (Table 4). The contributions of carbohydrate C, 
219 di-O-alkyl C and the whole O-alkyl regions were neither significantly different 220 between zones nor correlated with the environmental variables (Table 4, 221 Supplementary Table S1).

222 Neither index of degree of decomposition, the $A / O$ and $A / M$ ratios, showed any 223 consistent trend with increasing soil depth (Table 3). However, averaged across the $224 \quad 0-10 \mathrm{~cm}$ mineral layer, both the $\mathrm{A} / \mathrm{O}$ ratio and the $\mathrm{A} / \mathrm{M}$ ratio decreased significantly 225 with increasing soil pH $(P<0.05$, Table 4$)$, whereas no effect of soil texture (silt + clay) 226 was observed. The $\mathrm{A} / \mathrm{M}$ ratio also was correlated with climatic variables, as 227 significant positive relationships with MAP and AET were observed $(P<0.05$, Table 4). 228 Stepwise regression analysis also showed that $\mathrm{pH}$ was the most important variable in 229 controlling the $A / M$ ratio across these sites $\left(R^{2}=0.90, P=0.001\right.$, Table 2$)$.

\subsection{Soil organic C: Elemental and isotopic composition}

The $\mathrm{C} / \mathrm{N}$ ratios ranged from 10.16 in the $5-10 \mathrm{~cm}$ horizon of site $\mathrm{PG}$ to 30.16 for

232 the Oe horizon at site HYS (Fig. 3a). The $\mathrm{C} / \mathrm{N}$ ratios decreased with depth in the soil 233 profiles, and declined more dramatically in the forest floor than in the mineral soil.

234 The $\delta^{13} \mathrm{C}$ ranged from $-28.38 \%$ in the Oe horizon at site $\mathrm{YS}$ to $-17.63 \%$ o for the $5-10$ $235 \mathrm{~cm}$ horizon at site $\mathrm{HZY}$ (Fig. 3b). For a given horizon, the values of $\delta^{13} \mathrm{C}$ were higher in 236 the northern sites than in the southern sites with the striking exception of site HZY.

237 The $\delta^{15} \mathrm{~N}$ ranged from $-4.86 \%$ in the Oe horizon at site $X Y$ to $5.97 \%$ o for the $2-5 \mathrm{~cm}$ 238 horizon at site PG (Fig. 3c). Similar to $\delta^{13} \mathrm{C}$ values, $\delta^{15} \mathrm{~N}$ values also showed a 239 generally increasing trend with soil depth. However, no consistent trend was found 240 for $\delta^{15} \mathrm{~N}$ values among sites within a given horizon.

\section{4. Discussion}




\subsection{Soil organic C quantity}

We observed especially low forest floor carbon stocks in three of the sub-tropical oak forest stands (Fig. 2). Accumulation of SOC in surface organic layers is mainly driven by rates of $C$ input (litterfall and fine root turnover), by the biochemical quality of litter and by decomposition and mixing rates (Jandl et al. 2007). Focusing on one single tree species, the influence of litter quality was minimized in the present study. Although we did not measure litterfall, all the stands had closed canopies and in fact the largest trees and highest forest basal area were found in the three sub-tropical sites with low forest floor carbon stock (Table 1); hence, it seems unlikely that low litterfall inputs explain this pattern. More likely, higher temperature and moisture accelerate soil organic matter decay and reduce the accumulation of SOC in the organic layer; for example, Meentemeyer (1978) demonstrated the dependence of litter decay on site evapotranspiration, and distinctly higher annual actual evapotranspiration (AET) was estimated for the sub-tropical sites (Table 1). Another possible contributor might be soil invertebrates, e.g., earthworms and millipedes, which mix the forest floor into mineral soil (Nielsen and Hole 1964). Lin et al. (2009) observed that both the amount and diversity of forest floor macrofauna showed increasing trends from north to south in eight typical forest ecosystems across China. These increases might contribute to a faster litter decomposition and a reduced stock of forest floor $\mathrm{C}$ in the south.

Carbon stock in surface mineral soil showed no clear trend along the latitudinal gradient (Fig. 2). The factors controlling the accumulation of SOC in mineral layers are more complex than in the organic layer. In addition to the degree of microbial 
265 processing, it also depends on both the aboveground and belowground $\mathrm{C}$ sources

266 (Laganiere et al. 2013) as well as mechanisms of stabilization associated with clay

267 minerals and aggregation (Schmidt et al. 2011). We found a significantly negative

268 effect of clay + silt content (i.e., a positive effect of sand content) on SOC

269 concentration. Carter el al. (1998) proposed that the capacity of a soil to protect and

270 accumulate SOM in organomineral particles is not always positively related to the

271 clay and silt content per se but rather to the degree to which this capacity level is

272 filled. Once the clay plus silt is saturated with organic matter, additional SOM would

273 be found in macroaggregates, possibly as sand-sized macroorganic matter (Carter

274 2002). Also, although we did not measure it, certain clay minerals, especially

275 short-range ordered minerals, are particularly effective in SOC sequestration

276 (Kögel-Knabner et al. 2008) and perhaps the proportion of these minerals differs

277 among the sites. We also found a weak negative relationship between $\mathrm{pH}$ and

278 mineral soil $C$ concentration $\left(R^{2}=0.48, P=0.085\right)$. One possible explanation might be

279 that SOC had a higher solubility at high pH (Yin et al. 1996; Tavakkoli et al. 2015), and

280 more dissolved OC could lead to the reduced accumulation of SOC. Our findings

281 suggested that soil properties such as texture and $\mathrm{pH}$ were closely associated with

282 SOC accumulation.

283 4.2. Soil organic C composition based on NMR

284 The A/O ratio is widely used as an indicator of the degree of SOC degradation; 285 however, the A/O ratio did not show consistent patterns in some studies (Blumfield 286 et al. 2004; Lorenz et al. 2004). In the present study, among the three parts in the 287 O-alkyl region (methoxyl, carbohydrate, Di-O-alkyl), we only found a significant 
288 correlation between methoxyl C and the soil and climate variables (Table 4). Mathers

289 et al. (2007) suggested that the presence of a large amount of lignin will protect

290 some of the polysaccharide C from microbial attack and thus the O-alkyl C region

291 may overestimate the quantity of readily decomposable $\mathrm{C}$ when substantial amounts

292 of lignin are present; this might explain why the relative content of carbohydrate C in

293 our study was not sensitive to climate and soil variables. To better investigate the

294 links between the degree of SOC degradation and environmental variables, we

295 evaluated the alkyl-to-methoxyl (A/M) ratio. Showing similar patterns across sites,

296 the $\mathrm{A} / \mathrm{M}$ ratio had closer associations with soil and climatic factors than the $\mathrm{A} / \mathrm{O}$ ratio

297 (Table 4).

298 The alkyl/O-alkyl (A/O) ratio typically increases with progressive biodegradation

299 of labile OM components (Clemente et al. 2012). Contrary to previous reports of an

300 accumulation of alkyl $\mathrm{C}$ and hence an increased $\mathrm{A} / \mathrm{O}$ ratio with increasing soil depth

301 (Christensen 2001; Nierop et al. 2001), in our study neither the $A / O$ ratio, the $A / M$

302 ratio nor the alkyl C abundance showed any consistent variation with depth. We

303 speculate that a low A/O ratio of root detritus which is most abundant at these

304 shallow depths might contribute to this lack of depth pattern as suggested by Norris

305 et al. (2011). The limited depth sampling in the present study might also preclude

306 the detection of NMR patterns that occur at greater soil depths.

307 Instead, we found that both the $\mathrm{A} / \mathrm{M}$ ratios and the $\mathrm{A} / \mathrm{O}$ ratios were apparently

308 lower in the four northern sites for the $0-10 \mathrm{~cm}$ mineral soil compared to the three

309 southern sites, suggesting that the SOC in the northern sites is less decomposed

310 compared to the southern sites. In a comparable study along a boreal forest (Pinus 
311 banksiana) transect, Norris et al. (2011) observed a higher A/O ratio in the south,

312 and Kane et al. (2005) noted that the proportional amount of labile SOM in the

313 mineral soil decreased with increasing temperature in boreal Picea mariana forest.

314 The $0-10 \mathrm{~cm}$ mineral soil $\mathrm{pH}$ had a strong negative effect on both the $\mathrm{A} / \mathrm{M}$ ratio 315 and the A/O ratio across sites. Sinsabaugh (2010) stated that the laccases of white

316 rot fungi primarily involved in lignin breakdown generally have lower $\mathrm{pH}$ optima

317 (4.0-5.0); while the laccases of brown rot and coprophilic fungi, mainly active in 318 polymerizing soluble phenols and thereby contributing to humification, generally 319 have higher $\mathrm{pH}$ optima (6.0-7.5). With $\mathrm{pH}$ values ranging from 4.0 to 5.0 , lignin in the $320 \quad 0-10 \mathrm{~cm}$ mineral soil at the three southern sites may be more susceptible to 321 microbial attack than in the northern sites. We thus speculate that a faster 322 breakdown of lignin might contribute to the higher $A / M$ ratio and $A / O$ ratio in the 323 southern sites, but further investigation is needed. Besides the strong negative effect 324 of $\mathrm{pH}$, we also observed positive relationships between MAT, MAP and especially 325 AET on the A/M ratio. Our finding that $\mathrm{pH}$ was negatively affected by MAP and AET ( $\mathrm{r}$ $326=-0.78$ and $r=-0.76, P<0.05$; Table 4) suggests that differences in SOC composition 327 involve direct impacts of soil $\mathrm{pH}$ plus more complex interactions between climate 328 and soil properties.

\subsection{Soil organic C: Stable isotopes and $C / N$ ratio}

330 Decreases in $\mathrm{C} / \mathrm{N}$ ratio and increases in $\delta^{13} \mathrm{C}$ and $\delta^{15} \mathrm{~N}$ values with depth are 331 suggestive of increasing SOC stabilization with depth in our sites. One commonly 332 held theory is that the $\delta^{13} \mathrm{C}$ increases with depth are reflective of isotopic 333 discrimination that occurs during microbial decomposition (Garten Jr 2006; 
334 Nadelhoffer and Fry 1988), whereby microbes consume SOC, respire the light

335 isotope $\left({ }^{12} \mathrm{C}\right)$, and incorporate the heavier isotope $\left({ }^{13} \mathrm{C}\right)$ into biomass that is

336 subsequently deposited in the soil OM complex. As this process proceeds SOC

337 particles decompose into smaller sizes, which then physically migrate downward

338 (Acton et al. 2013; Kayler et al. 2011). The C/N ratio of soil OM also decreases with

339 progressive biodegradation because plant-derived OM contains less nitrogen than

340 microbial-derived OM (Baumann et al. 2009). Thus, as plant material is degraded, the

341 proportion of carbon declines and nitrogen increases (Simpson and Simpson 2012).

342 With one exception (site $\mathrm{HZY}$ ) soil $\delta^{13} \mathrm{C}$ values were higher in the temperate

343 zone than in the sub-tropical sites for a given horizon (Fig. 3b). Grass understory

344 vegetation beneath Quercus variabilis was only observed in sub-tropical site HZY;

345 thus, the exceptionally high $\delta^{13} \mathrm{C}$ there might be explained by a historical influence of

346 C4 grasses contributing to $\mathrm{SOC}$, as $\delta^{13} \mathrm{C}$ is much higher for $\mathrm{C} 4$ than $\mathrm{C} 3$ plant tissue

347 (Vitorello et al. 1989). A simple interpretation of the slightly lower delta ${ }^{13} \mathrm{C}$ in the

348 other sub-tropical than the temperate sites is not possible as Balesdent et al. (1993)

349 indicated wide variation in tree tissue $\delta^{13} \mathrm{C}$ within a single climatic region. However,

350 in the present study, leaf $\delta^{13} \mathrm{C}$ value had a strong negative relationship with mean

351 annual precipitation $\left(\mathrm{R}^{2}=0.91, P=0.001\right.$; Supplementary Fig. S2) and decreased

352 from north to south. Therefore, it seems likely that differences in soil $\delta^{13} \mathrm{C}$ between

353 the temperate and sub-tropical zones reflected differences in detrital sources rather

354 than degree of decomposition.

355 In summary, to our knowledge, this is the first regional investigation on SOC

356 quantity and degree of decomposition encompassing warm-temperate to 
357 sub-tropical forest zones with control for tree species composition. We have

358 explored two methods to characterize the degree of SOC degradation. The NMR

359 analysis provided the best index of degree of SOC degradation across the climatic

360 gradient whereas isotopic composition $\left(\delta^{13} \mathrm{C}\right)$ better reflected the degree of SOC

361 decomposition along the soil depth gradient. Site differences in litter isotopic

362 composition might have masked the latitudinal variation in SOC degradation. Thus,

363 our results highlight the importance of using different techniques for characterizing

364 SOC. No fully consistent latitudinal patterns were observed for SOC quantity. The

365 alkyl/methoxyl ratio, based on NMR spectra, appeared to provide the most

366 informative index of degree of SOC decomposition. This index was strongly related to

367 soil $\mathrm{pH}$, indicating a greater degree of $\mathrm{SOC}$ degradation at lower soil $\mathrm{pH}$ in the wetter

368 sub-tropical sites, which may reflect the effect of climate on $\mathrm{pH}$ together with the

369 effect of $\mathrm{pH}$ on laccase enzymes. Further study of the interactions among

370 macroclimate, soil development and SOC under controlled conditions of vegetation

371 composition could contribute to improved understanding of controls on SOC 372 accumulation in forest soils.

\section{Acknowledgements}

374 We are grateful to Yunqiang Xia, Shengjun Gu, Fengjie Li, Li Zhang, Jieli Wu, Bona Dai,

375 Xuyi Zhang and Baoming Du for their assistance in field work and laboratory analyses.

376 We thank the two anonymous reviewers for their comments that improved the 377 clarity of the manuscript. This work was financially supported by the National

378 Natural Science Foundation of China (No. 31270491), SJTU Agri-X funding (No. 379 Agri-X2015004) and SJTU SMC-B. 


\section{References}

Acton, P., Fox, J., Campbell, E., Rowe, H., and Wilkinson, M. 2013. Carbon isotopes for estimating soil decomposition and physical mixing in well-drained forest soils. J Geophys Res-Biogeo 118(4): 1532-1545. doi:10.1002/2013JG002400.

Baldock, J., Oades, J., Nelson, P., Skene, T., Golchin, A., Clarke, P., Skjemstad, J., Bell, M., and Bridge, B. 1997. Assessing the extent of decomposition of natural organic materials using solid-state ${ }^{13}$ C NMR spectroscopy. Aust J Soil Res 35(5): 1061-1084. doi:10.1071/S97004.

Balesdent, J., Girardin, C., and Mariotti, A. 1993. Site-related $\delta^{13} \mathrm{C}$ of tree leaves and soil organic matter in a temperate forest. Ecology: 1713-1721. doi:10.2307/1939930

Baumann, K., Marschner, P., Smernik, R.J., and Baldock, J.A. 2009. Residue chemistry and microbial community structure during decomposition of eucalypt, wheat and vetch residues. Soil Biol Biochem 41(9): 1966-1975. doi:10.1016/j.soilbio.2009.06.022.

Berg, B. 2000. Litter decomposition and organic matter turnover in northern forest soils. Forest Ecol Manag 133(1): 13-22. doi:10.1016/S0378-1127(99)00294-7.

Blumfield, T.J., Xu, Z.H., Mathers, N.J., and Saffigna, P.G. 2004. Decomposition of nitrogen-15 labeled hoop pine harvest residues in subtropical Australia. Soil Sci Soc Am J 68(5): 1751-1761. doi:10.2136/sssaj2004.1751

Carter, M.R., Gregorich, E.G., Angers, D.A., Donald, R.G., and Bolinder, M.A. 1998. Organic $\mathrm{C}$ and $\mathrm{N}$ storage, and organic $\mathrm{C}$ fractions, in adjacent cultivated and 
forested soils of eastern Canada. Soil Till Res 47: 253-261. doi:10.1016/S0167-1987(98)00114-7.

Carter, M. R. 2002. Soil quality for sustainable land management: organic matter and aggregation interactions that maintain soil functions. Agron J 94: 38-47. doi:10.2134/agronj2002.3800

Christensen, B.T. 2001. Physical fractionation of soil and structural and functional complexity in organic matter turnover. Eur J Soil Sci 52(3): 345-353. doi:10.1046/j.1365-2389.2001.00417.x.

Clemente, J.S., Gregorich, E.G., Simpson, A.J., Kumar, R., Courtier-Murias, D., and Simpson, M.J. 2012. Comparison of nuclear magnetic resonance methods for the analysis of organic matter composition from soil density and particle fractions. Environ Chem 9(1): 97-107. doi:10.1071/En11096.

Ding, B.Y. 2013. Citing online sources: The calculation method of evapotranspiration. Available from http://www.docin.com/p-596310449.html [accessed 29 January 2016].

Du, B., Kang, H., Pumpanen, J., Zhu, P., Yin, S., Zou, Q., Wang, Z., Kong, F., and Liu, C. 2014. Soil organic carbon stock and chemical composition along an altitude gradient in the Lushan Mountain, subtropical China. Ecol Res 29(3): 433-439. doi:10.1007/s11284-014-1135-4.

Elliott, E.T., Heil, J.W., Kelly, E.F., and Monger, H.C. 1999. Soil structural and other physical properties. In Standard soil methods for long-term ecological research. Oxford University Press, New York, New York, USA. pp. 78-80. 
Eswaran, H., Van Den Berg, E., and Reich, P. 1993. Organic carbon in soils of the world. Soil Sci Soc Am J 57(1): 192-194. doi:10.2136/sssaj1993.03615995005700010034x

Garten Jr, C.T. 2006. Relationships among forest soil C isotopic composition, partitioning, and turnover times. Can J For Res 36(9): 2157-2167. doi:10.1139/X06-115.

Goodale, C.L., Apps, M.J., Birdsey, R.A., Field, C.B., Heath, L.S., Houghton, R.A., Jenkins, J.C., Kohlmaier, G.H., Kurz, W., Liu, S.R., Nabuurs, G.J., Nilsson, S., and Shvidenko, A.Z. 2002. Forest carbon sinks in the Northern Hemisphere. Ecol Appl 12(3): 891-899. doi:10.2307/3060997.

Guillaume, T., Damris, M., and Kuzyakov, Y. 2015. Losses of soil carbon by converting tropical forest to plantations: erosion and decomposition estimated by $\delta^{13} \mathrm{C}$. Global Change Biol 21(9): 3548-3560. doi:10.1111/gcb.12907.

Hobbie, S.E., Reich, P.B., Oleksyn, J., Ogdahl, M., Zytkowiak, R., Hale, C., and Karolewski, P. 2006. Tree species effects on decomposition and forest floor dynamics in a common garden. Ecology 87(9): 2288-2297. doi:10.1890/0012-9658(2006)87[2288:Tseoda]2.0.Co;2.

Jandl, R., Lindner, M., Vesterdal, L., Bauwens, B., Baritz, R., Hagedorn, F., Johnson, D.W., Minkkinen, K., and Byrne, K.A. 2007. How strongly can forest management influence soil carbon sequestration? Geoderma 137(3-4): 253-268. doi:10.1016/j.geoderma.2006.09.003.

Johnsen, K.H., Samuelson, L.J., Sanchez, F.G., and Eaton, R.J. 2013. Soil carbon and nitrogen content and stabilization in mid-rotation, intensively managed 
sweetgum and loblolly pine stands. Forest Ecol Manag 302: 144-153. doi:10.1016/j.foreco.2013.03.016.

Kögel-Knabner, I. $1997 .{ }^{13} \mathrm{C}$ and ${ }^{15} \mathrm{~N}$ NMR spectroscopy as a tool in soil organic matter studies. Geoderma 80(3): 243-270. doi:10.1016/S0016-7061(97)00055-4.

Kögel-Knabner, I., Ekschmitt, K., Flessa, H., Guggenberger, G., Matzner, E., Marschner, B., and von Lüetzow, M. 2008. An integrative approach of organic matter stabilization in temperate soils: Linking chemistry, physics, and biology. Journal of Plant Nutrition and Soil Science 171(1): 5-13. doi:10.1002/jpln.200700215.

Kane, E.S., Valentine, D.W., Schuur, E.A.G., and Dutta, K. 2005. Soil carbon stabilization along climate and stand productivity gradients in black spruce forests of interior Alaska. Can J Forest Res 35(9): 2118-2129. doi:10.1139/X05-093.

Kang, H., Liu, C., Yu, W., Wu, L., Chen, D., Sun, X., Ma, X., Hu, H., and Zhu, X. 2011. Variation in foliar $\delta^{15} \mathrm{~N}$ among oriental oak (Quercus variabilis) stands over eastern China: patterns and interactions. J Geochem Explor 110(1): 8-14. doi:10.1016/j.gexplo.2011.02.002.

Kayler, Z.E., Kaiser, M., Gessler, A., Ellerbrock, R.H., and Sommer, M. 2011. Application of $\delta^{13} \mathrm{C}$ and $\delta^{15} \mathrm{~N}$ isotopic signatures of organic matter fractions sequentially separated from adjacent arable and forest soils to identify carbon stabilization mechanisms. Biogeosciences 8(10): 2895-2906. doi:10.5194/bg-8-2895-2011. 
Laganiere, J., Pare, D., Bergeron, Y., Chen, H.Y.H., Brassard, B.W., and Cavard, X. 2013. Stability of soil carbon stocks varies with forest composition in the Canadian Boreal Biome. Ecosystems 16(5): 852-865. doi:10.1007/s10021-013-9658-z.

Lin, Y., Sun, J., and Zhang, D. 2009. Characteristics of soil fauna community in forest floor at different climate zone, China. Acta Ecologica Sinica 29(6): 2938-2944.

Liski, J., Ilvesniemi, H., Mäkelä, A., and Westman, C.J. 1999. CO 2 emissions from soil in response to climatic warming are overestimated: the decomposition of old soil organic matter is tolerant of temperature. Ambio: 171-174.

Lorenz, K., Preston, C.M., Krumrei, S., and Feger, K.H. 2004. Decomposition of needle/leaf litter from Scots pine, black cherry, common oak and European beech at a conurbation forest site. Eur J For Res 123(3): 177-188. doi:10.1007/s10342-004-0025-7.

Mathers, N.J., Jalota, R.K., Dalal, R.C., and Boyd, S.E. 2007. ${ }^{13}$ C-NMR analysis of decomposing litter and fine roots in the semi-arid Mulga Lands of southern Queensland. Soil Biol Biochem 39(5): 993-1006. doi:10.1016/j.soilbio.2006.11.009.

Meentemeyer, V. 1978. Macroclimate and lignin control of litter decomposition rates. Ecology 59(3): 465-472. doi:10.2307/1936576.

Nadelhoffer, K., and Fry, B. 1988. Controls on natural nitrogen-15 and carbon-13 abundances in forest soil organic matter. Soil Sci Soc Am J 52(6): 1633-1640. doi:10.2136/sssaj1988.03615995005200060024x. 
Nielsen, G.A., and Hole, F.D. 1964. Earthworms and the development of coprogenous A1 horizons in forest soils of Wisconsin. Soil Sci Soc Am J 28(3): 426-430. doi:10.2136/sssaj1964.03615995002800030037x.

Nierop, K.G.J., van Lagen, B., and Buurman, P. 2001. Composition of plant tissues and soil organic matter in the first stages of a vegetation succession. Geoderma 100(1-2): 1-24. doi:10.1016/S0016-7061(00)00078-1.

Norris, C.E., Quideau, S.A., Bhatti, J.S., and Wasylishen, R.E. 2011. Soil carbon stabilization in jack pine stands along the Boreal Forest Transect Case Study. Global Change Biol 17(1): 480-494. doi:10.1111/j.1365-2486.2010.02236.x.

Pendall, E., Bridgham, S., Hanson, P.J., Hungate, B., Kicklighter, D.W., Johnson, D.W., Law, B.E., Luo, Y.Q., Megonigal, J.P., Olsrud, M., Ryan, M.G., and Wan, S.Q. 2004. Below-ground process responses to elevated $\mathrm{CO} 2$ and temperature: a discussion of observations, measurement methods, and models. New Phytol 162(2): 311-322. doi:10.1111/j.1469-8137.2004.01053.x.

Preston, C.M., Trofymow, J., the, and Working Group, t.C.I.D.E. 2000. Variability in litter quality and its relationship to litter decay in Canadian forests. Can J Botany 78(10): 1269-1287. doi:10.1139/b00-101

Quideau, S., Anderson, M., Graham, R., Chadwick, O., and Trumbore, S. 2000. Soil organic matter processes: characterization by ${ }^{13} \mathrm{C} N \mathrm{NMR}$ and ${ }^{14} \mathrm{C}$ measurements. Forest Ecol Manag 138(1): 19-27. doi:10.1016/S0378-1127(00)00409-6.

Schmidt, M.W.I., Torn, M.S., Abiven, S., Dittmar, T., Guggenberger, G., Janssens, I.A., Kleber, M., Kogel-Knabner, I., Lehmann, J., Manning, D.A.C., Nannipieri, P., Rasse, D.P., Weiner, S., and Trumbore, S.E. 2011. Persistence of soil organic 
matter as an ecosystem property. Nature 478(7367): 49-56. doi:10.1038/nature10386.

Schneckenberger, K., and Kuzyakov, Y. 2007. Carbon sequestration under Miscanthus in sandy and loamy soils estimated by natural ${ }^{13} \mathrm{C}$ abundance. J Plant Nutr Soil Sci 170(4): 538-542. doi:10.1002/jpln.200625111.

Simpson, M.J., Otto, A., and Feng, X.J. 2008. Comparison of solid-state carbon-13 nuclear magnetic resonance and organic matter biomarkers for assessing soil organic matter degradation. Soil Sci Soc Am J 72(1): 268-276. doi:10.2136/sssaj2007.0045.

Simpson, M.J., and Simpson, A.J. 2012. The chemical ecology of soil organic matter molecular constituents. J Chem Ecol 38(6): 768-784. doi:10.1007/s10886-012-0122-x.

Sinsabaugh, R.L. 2010. Phenol oxidase, peroxidase and organic matter dynamics of soil. Soil Biol Biochem 42(3): 391-404. doi:10.1016/j.soilbio.2009.10.014.

Sjogersten, S., Turner, B.L., Mahieu, N., Condron, L.M., and Wookey, P.A. 2003. Soil organic matter biochemistry and potential susceptibility to climatic change across the forest-tundra ecotone in the Fennoscandian mountains. Global Change Biol 9(5): 759-772. doi:10.1046/j.1365-2486.2003.00598.x.

Tavakkoli, E., Rengasamy, P., Smith, E., and McDonald, G. K. 2015. The effect of cation-anion interactions on soil $\mathrm{pH}$ and solubility of organic carbon. Eur J For Res 66(6): 1054-1062. doi:10.1111/ejss.12294. 
Vane, C.H., Drage, T.C., and Snape, C.E. 2006. Bark decay by the white-rot fungus Lentinula edodes: polysaccharide loss, lignin resistance and the unmasking of suberin. Int Biodeter Biodegr 57(1): 14-23. doi:10.1016/j.ibiod.2005.10.004.

Vitorello, V.A., Cerri, C.C., Victória, R., Andreux, F., and Feller, C. 1989. Organic matter and natural carbon-13 distribution in forested and cultivated oxisols. Soil Sci Soc Am J 53(3): 773-778. doi:10.2136/sssaj1989.03615995005300030024x.

von Lützow, M., Kögel-Knabner, I., Ekschmitt, K., Matzner, E., Guggenberger, G., Marschner, B., and Flessa, H. 2006. Stabilization of organic matter in temperate soils: mechanisms and their relevance under different soil conditions - a review. Eur J Soil Sci 57(4): 426-445. doi:10.1111/j.1365-2389.2006.00809.x.

Wang, Q.K., Wang, S.L., and Zhong, M.C. 2013. Ecosystem carbon storage and soil organic carbon stability in pure and mixed stands of Cunninghamia lanceolata and Michelia macclurei. Plant Soil 370(1-2): 295-304. doi:10.1007/s11104-013-1631-2.

Whitby, T.G., and Madritch, M.D. 2013. Native temperature regime influences soil response to simulated warming. Soil Biol Biochem 60: 202-209. doi:10.1016/j.soilbio.2013.01.014.

Xu, X., Shi, Z., Li, D.J., Rey, A., Ruan, H.H., Craine, J.M., Liang, J.Y., Zhou, J.Z., and Luo, Y.Q. 2016. Soil properties control decomposition of soil organic carbon: Results from data-assimilation analysis. Geoderma 262: 235-242. doi:10.1016/j.geoderma.2015.08.038. 
Yin, Y., Allen, H. E., Li, Y., Huang, C., and Sanders, P. F. 1996. Adsorption of mercury (II) by soil: effects of $\mathrm{pH}$, chloride, and organic matter. J Environ Qual 25(4): 837-844. doi:10.2134/jeq1996.00472425002500040027x.

Yuste, J.C., Barba, J., Fernandez-Gonzalez, A.J., Fernandez-Lopez, M., Mattana, S., Martinez-Vilalta, J., Nolis, P., and Lloret, F. 2012. Changes in soil bacterial community triggered by drought-induced gap succession preceded changes in soil C stocks and quality. Ecol Evol 2(12): 3016-3031. doi:10.1002/ece3.409. 
Table 1 Selected climate, stand and mineral soil characteristics at seven forest study sites composed of Quercus variabilis in China.

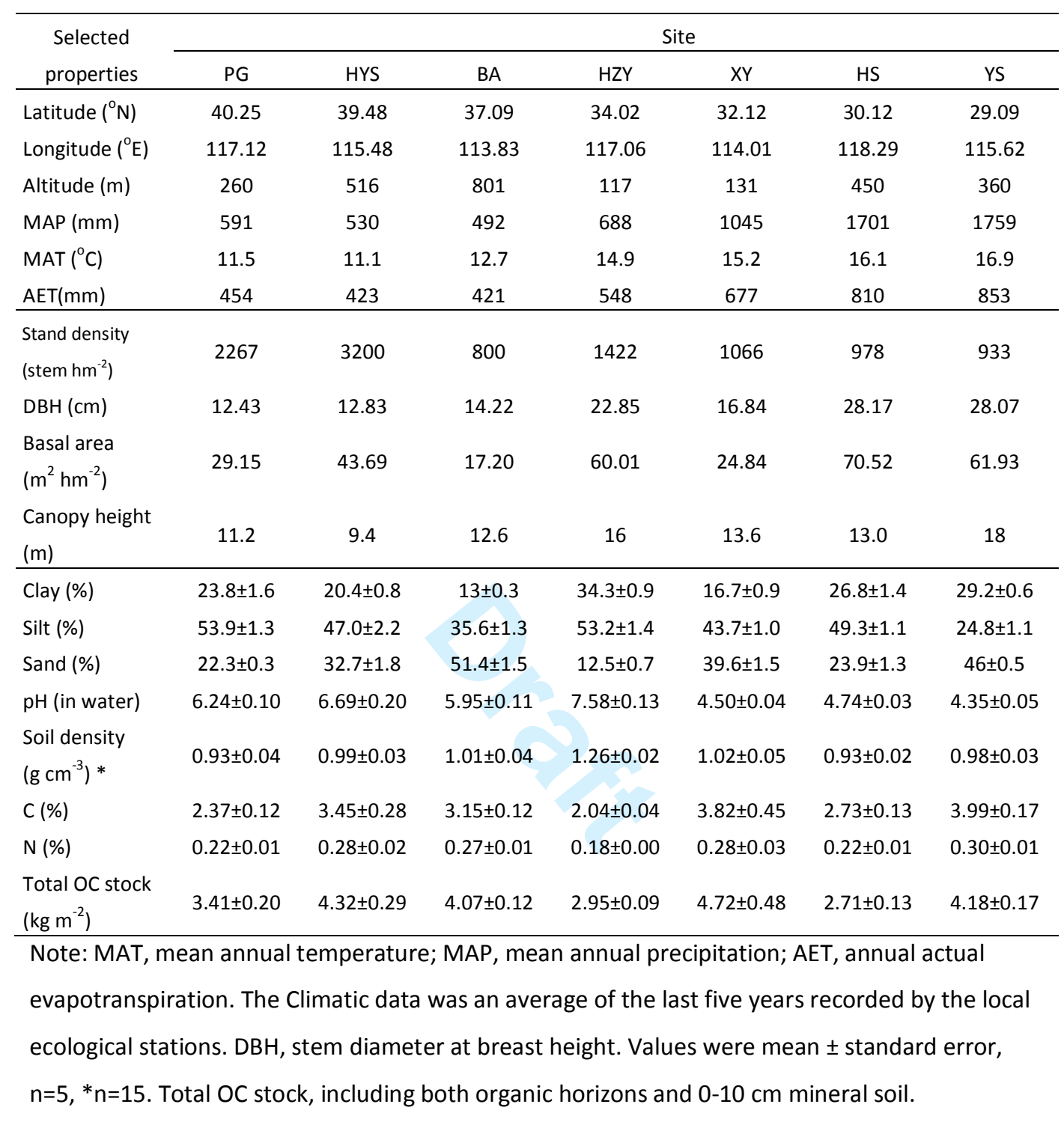


Table 2 Stepwise multi-regression analysis of SOC quantity and composition with soil and climatic variables

\begin{tabular}{cccccc}
\hline $\begin{array}{c}\text { SOC quantity and } \\
\text { composition }\end{array}$ & $\begin{array}{c}\text { Variables } \\
\text { entered }\end{array}$ & $\mathrm{R}^{2}$ & $\mathrm{n}$ & $P$ & Regression \\
\hline C concentration (\%) & Clay + silt & 0.66 & 7 & 0.026 & $\mathrm{y}=-0.04 \mathrm{x}+5.94$ \\
A/O ratio & $\mathrm{pH}$ & 0.73 & 7 & 0.014 & $\mathrm{y}=-0.04 \mathrm{x}+0.84$ \\
A/M ratio & $\mathrm{pH}$ & 0.90 & 7 & 0.001 & $\mathrm{y}=-0.37 \mathrm{x}+5.25$ \\
\hline
\end{tabular}

Note: Variables used in the regression analysis: clay + silt content, $\mathrm{pH}$ value, mean annual temperature, mean annual precipitation, annual actual evapotranspiration. For $\mathrm{C}$ stock, none of the five variables entered into the model. 
Table 3 SOC composition (\%) in different soil depths at seven study sites using CP-MAS ${ }^{13} \mathrm{C}$ NMR. Sites are arranged in order of decreasing latitude.

\begin{tabular}{|c|c|c|c|c|c|c|c|c|c|c|c|}
\hline Site & $\begin{array}{l}\text { Depth } \\
\text { (cm) }\end{array}$ & Alkyl & N-alkyl/Methoxyl & Carbohydrate & Di-O-alkyl & Aryl & O-aryl & Carboxyl & Ketone & $\begin{array}{l}\mathrm{A} / \mathrm{O} \\
\text { ratio }\end{array}$ & $\begin{array}{l}\mathrm{A} / \mathrm{M} \\
\text { ratio }\end{array}$ \\
\hline & $0-2$ & 26.41 & 9.96 & 29.28 & 8.31 & 9.44 & 4.38 & 10.17 & 2.05 & 0.56 & 2.65 \\
\hline \multirow[t]{3}{*}{ PG } & $2-5$ & 24.41 & 9.89 & 30.28 & 8.46 & 9.36 & 4.19 & 11.16 & 2.25 & 0.50 & 2.48 \\
\hline & $5-10$ & 27.28 & 9.48 & 28.65 & 7.69 & 10.11 & 4.12 & 10.78 & 1.89 & 0.60 & 2.88 \\
\hline & $0-2$ & 26.08 & 10.83 & 29.68 & 7.85 & 9.01 & 3.93 & 10.78 & 1.84 & 0.54 & 2.42 \\
\hline \multirow[t]{3}{*}{ HYS } & $2-5$ & 28.20 & 11.03 & 30.00 & 7.47 & 8.83 & 3.13 & 10.22 & 1.13 & 0.58 & 2.57 \\
\hline & $5-10$ & 29.15 & 9.50 & 28.88 & 7.42 & 9.31 & 3.37 & 10.82 & 1.55 & 0.64 & 3.07 \\
\hline & $0-2$ & 27.76 & 10.28 & 29.84 & 7.77 & 8.54 & 3.70 & 10.26 & 1.85 & 0.58 & 2.70 \\
\hline \multirow[t]{3}{*}{ BA } & $2-5$ & 27.33 & 10.00 & 29.96 & 7.57 & 8.51 & 3.80 & 10.81 & 2.03 & 0.58 & 2.74 \\
\hline & 5-10 & 27.25 & 9.03 & 30.54 & 7.98 & 9.43 & 3.42 & 10.49 & 1.85 & 0.57 & 3.02 \\
\hline & $0-2$ & 24.85 & 10.31 & 30.95 & 8.65 & 8.33 & 4.08 & 10.69 & .15 & 0.50 & 2.41 \\
\hline \multirow[t]{3}{*}{$\mathrm{HZY}$} & $2-5$ & 26.88 & 10.33 & 30.57 & 8.14 & 7.57 & 3.50 & 10.98 & 2.03 & 0.55 & 2.60 \\
\hline & $5-10$ & 27.63 & 10.11 & 31.07 & 8.08 & 7.56 & 3.02 & 10.88 & 1.65 & 0.56 & 2.73 \\
\hline & $0-2$ & 28.94 & 9.02 & 30.09 & 7.87 & 8.27 & 4.21 & 9.40 & .20 & 0.62 & 3.21 \\
\hline \multirow[t]{3}{*}{$X Y$} & $2-5$ & 30.62 & 8.19 & 29.40 & 7.74 & 8.33 & 3.63 & 9.94 & 2.15 & 0.68 & 3.75 \\
\hline & 5-10 & 33.20 & 8.43 & 28.61 & 7.36 & 7.79 & 3.42 & 9.32 & 1.87 & 0.75 & 3.94 \\
\hline & $0-2$ & 27.55 & 9.49 & 34.65 & 8.46 & 6.87 & 2.52 & 9.12 & 1.34 & 0.53 & 3.00 \\
\hline \multirow[t]{3}{*}{ HS } & $2-5$ & 31.18 & 8.51 & 32.38 & 7.75 & 7.56 & 2.29 & 9.10 & 1.25 & 0.64 & 3.67 \\
\hline & $5-10$ & 30.21 & 8.54 & 32.99 & 7.59 & 7.76 & 1.92 & 9.71 & 1.28 & 0.62 & 3.54 \\
\hline & $0-2$ & 30.35 & 8.48 & 30.12 & 7.54 & 8.31 & 3.14 & 10.29 & 1.77 & 0.66 & 3.58 \\
\hline \multirow[t]{2}{*}{ YS } & $2-5$ & 28.94 & 8.85 & 29.84 & 7.61 & 8.79 & 3.00 & 11.05 & 1.93 & 0.63 & 3.29 \\
\hline & $5-10$ & 31.11 & 7.88 & 29.52 & 6.87 & 9.17 & 2.25 & 11.54 & 1.66 & 0.70 & 3.95 \\
\hline PG & & 26.25 & 9.70 & 29.27 & 8.04 & 9.75 & 4.19 & 10.77 & 2.03 & 0.56 & 2.71 \\
\hline HYS & & 28.25 & 10.22 & 29.38 & 7.52 & 9.10 & 3.41 & 10.63 & 1.48 & 0.59 & 2.79 \\
\hline BA & & 27.38 & 9.57 & 30.22 & 7.82 & 8.98 & 3.59 & 10.54 & 1.90 & 0.58 & 2.87 \\
\hline $\mathrm{HZY}$ & $0-10$ & 26.85 & 10.22 & 30.90 & 8.21 & 7.72 & 3.37 & 10.87 & 1.86 & 0.54 & 2.63 \\
\hline$X Y$ & & 31.58 & 8.48 & 29.15 & 7.57 & 8.05 & 3.64 & 9.52 & 2.02 & 0.70 & 3.74 \\
\hline $\mathrm{HS}$ & & 29.97 & 8.72 & 33.14 & 7.81 & 7.52 & 2.15 & 9.40 & 1.29 & 0.61 & 3.47 \\
\hline YS & & 30.31 & 8.29 & 29.73 & 7.22 & 8.89 & 2.66 & 11.14 & 1.76 & 0.67 & 3.68 \\
\hline
\end{tabular}

Note: Values were mean of two replicates. 
Table 4 Pearson correlations ( $r$ ) among SOC and soil and climatic variables across seven oak forest study sites in China ( $N=7)$.

\begin{tabular}{lccccc}
\hline & Clay + silt (\%) & $\mathrm{pH}$ & $\mathrm{MAT}\left({ }^{\circ} \mathrm{C}\right)$ & $\mathrm{MAP}(\mathrm{mm})$ & $\mathrm{AET}(\mathrm{mm})$ \\
\hline C stock $\left(\mathrm{kg} \mathrm{m}^{-2}\right.$ ) & -0.75 & -0.32 & -0.17 & -0.16 & -0.12 \\
C concentration (\%) & $-0.81^{*}$ & -0.69 & 0.25 & 0.37 & 0.36 \\
Alkyl C (\%) & -0.41 & $-0.85^{*}$ & 0.67 & 0.72 & $0.76^{*}$ \\
N-alkyl/Methoxyl C (\%) & 0.47 & $0.97^{* *}$ & -0.75 & $-0.83^{*}$ & $-0.85^{*}$ \\
Carbohydrate C (\%) & 0.37 & -0.09 & 0.46 & 0.47 & 0.43 \\
Di-O-alkyl C (\%) & 0.71 & 0.68 & -0.30 & -0.51 & -0.47 \\
O-alkyl C (\%) & 0.64 & 0.51 & -0.03 & -0.10 & -0.14 \\
A/O ratio (\%) & -0.55 & $-0.86^{*}$ & 0.57 & 0.61 & 0.66 \\
A/M ratio (\%) & -0.45 & $-0.95^{* *}$ & 0.75 & $0.82^{*}$ & $0.85^{*}$ \\
\hline Clay + silt (\%) & & 0.55 & -0.06 & -0.12 & -0.08 \\
pH & & & -0.61 & $-0.78^{*}$ & $-0.76^{*}$ \\
MAT ( $\left.{ }^{\circ} \mathrm{C}\right)$ & & & & $0.86^{*}$ & $0.93^{* *}$ \\
MAP (mm) & & & & & $0.98^{* *}$ \\
\hline
\end{tabular}

Note: ${ }^{* * P}<0.01 ;{ }^{*} \mathrm{P}<0.05$. 
Figure captions

Fig. 1. Distribution of the seven oriental oak forest sites along a 1500-km climatic gradient in East China. Three sites (PG, HYS, BA) are in the warm temperate zone, four sites (HZY, XY, HS, YS) are in the sub-tropical zone.

Fig.2. Soil organic carbon stock $\left(\mathrm{kg} \mathrm{m}^{-2}\right)$ in organic and mineral layers in seven oriental oak stands. Values were mean \pm standard error, $n=5$.

Fig. 3. Elemental and isotopic composition of organic matter in forest floor and mineral soils in oriental oak stands along the latitudinal gradient. (a), C/N ratios; (b), delta ${ }^{13} \mathrm{C}$; (c), delta ${ }^{15} \mathrm{~N}$. Values were mean \pm standard error, $n=5$. 
Fig. 1

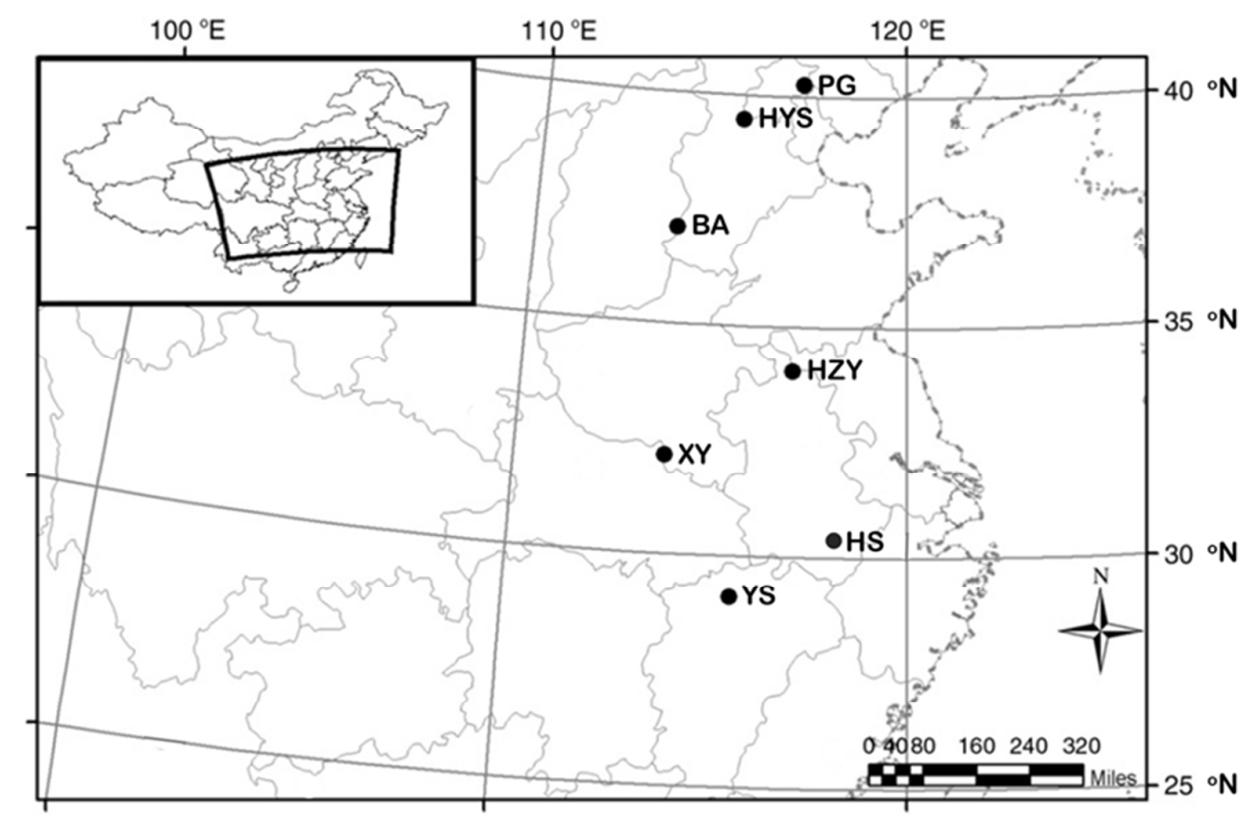


Fig. 2

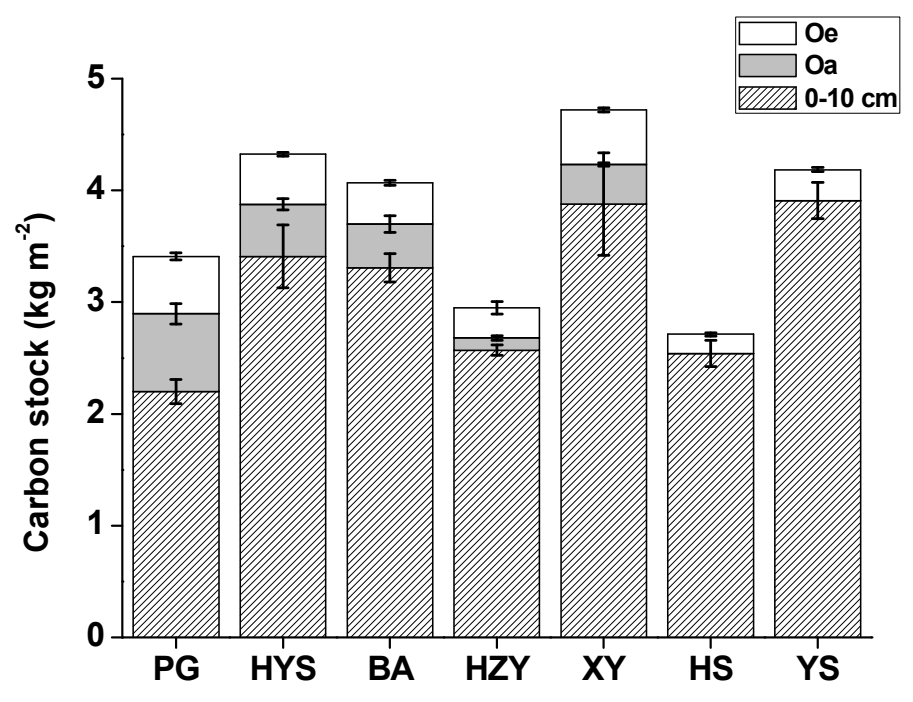


Fig. 3

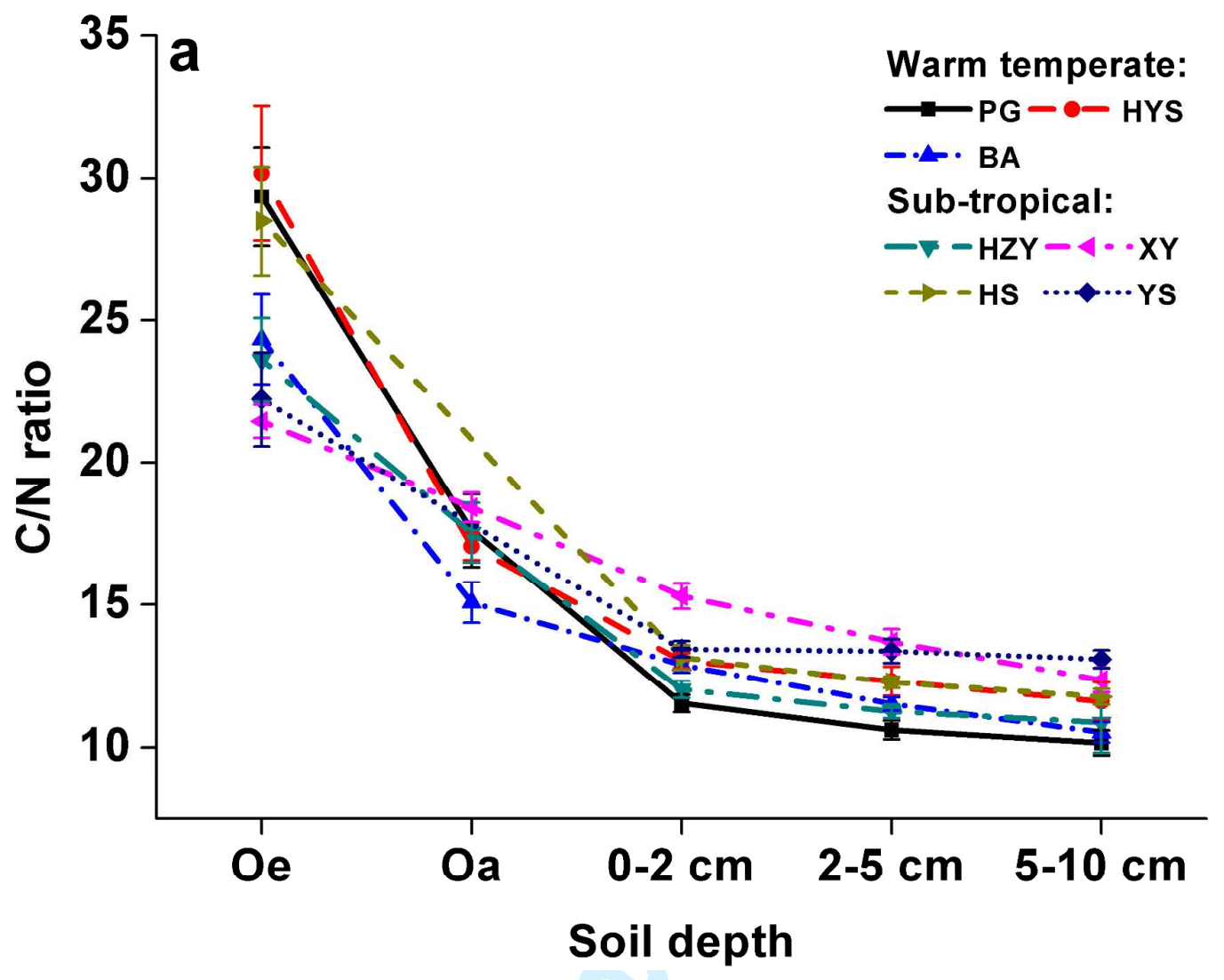



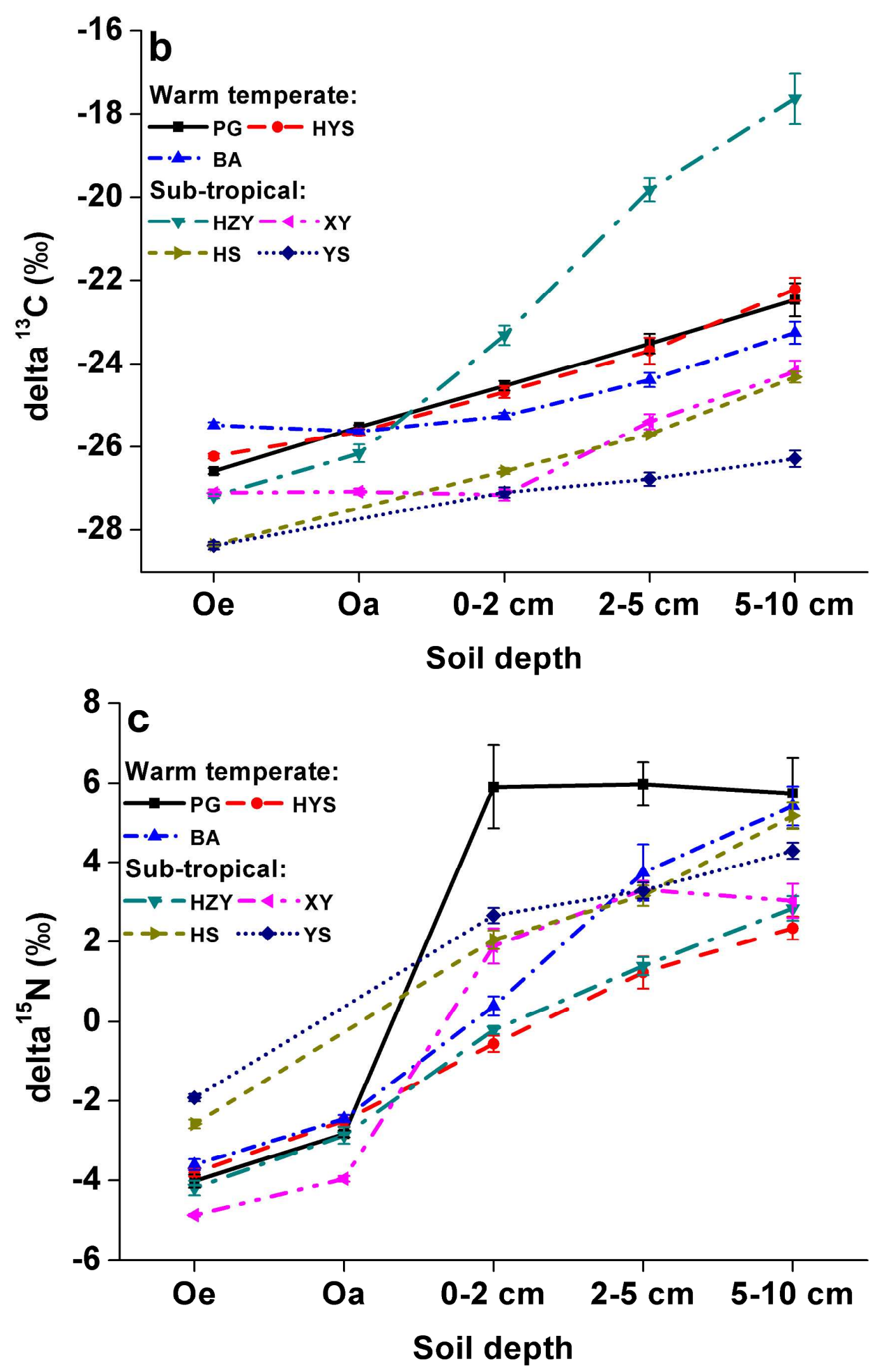
Supplementary Table S1 Results of analysis of variance for the effects: (A) on carbon stock of zone; (B) on isotopic composition of zone for each depth layer; and (C) SOC composition $(0-10 \mathrm{~cm})$ of zone

\begin{tabular}{|c|c|c|c|c|}
\hline Subject & Effect & $\mathrm{DF}$ & F value & $P_{r}>F$ \\
\hline \multicolumn{5}{|l|}{ A. Carbon stock $\left(\mathrm{kg} \mathrm{m}^{-2}\right)$} \\
\hline Forest floor horizon & Zone & 1 & 34.88 & $<0.001$ \\
\hline $0-10 \mathrm{~cm}$ mineral horizon & Zone & 1 & 0.86 & 0.359 \\
\hline \multicolumn{4}{|l|}{ B. Isotopic composition } & \\
\hline $\mathrm{C} / \mathrm{N}$ ratio & Zone & 1 & 13.86 & 0.001 \\
\hline$\delta^{13} \mathrm{C}$ & Zone & 1 & 69.30 & $<0.001$ \\
\hline$\delta^{15} \mathrm{~N}$ & Zone & 1 & 1.66 & 0.206 \\
\hline \multicolumn{5}{|l|}{ Oa* } \\
\hline $\mathrm{C} / \mathrm{N}$ ratio & Zone & 1 & 7.78 & 0.010 \\
\hline$\delta^{13} \mathrm{C}$ & Zone & 1 & 42.54 & $<0.001$ \\
\hline$\delta^{15} \mathrm{~N}$ & Zone & 1 & 18.36 & $<0.001$ \\
\hline \multicolumn{5}{|l|}{$0-2 \mathrm{~cm}$} \\
\hline $\mathrm{C} / \mathrm{N}$ ratio & Zone & 1 & 7.52 & 0.010 \\
\hline$\delta^{13} \mathrm{C}$ & Zone & 1 & 7.70 & 0.009 \\
\hline$\delta^{15} \mathrm{~N}$ & Zone & 1 & 0.09 & 0.767 \\
\hline \multicolumn{5}{|l|}{$2-5 \mathrm{~cm}$} \\
\hline $\mathrm{C} / \mathrm{N}$ ratio & Zone & 1 & 13.23 & 0.001 \\
\hline$\delta^{13} \mathrm{C}$ & Zone & 1 & 0.58 & 0.454 \\
\hline$\delta^{15} \mathrm{~N}$ & Zone & 1 & 2.30 & 0.139 \\
\hline \multicolumn{5}{|l|}{$5-10 \mathrm{~cm}$} \\
\hline $\mathrm{C} / \mathrm{N}$ ratio & Zone & 1 & 15.98 & $<0.001$ \\
\hline$\delta^{13} \mathrm{C}$ & Zone & 1 & 0.25 & 0.620 \\
\hline$\delta^{15} \mathrm{~N}$ & Zone & 1 & 1.99 & 0.168 \\
\hline \multicolumn{5}{|c|}{ C. SOC composition $(0-10 \mathrm{~cm})$} \\
\hline Alkyl C (\%) & Zone & 1 & 7.11 & 0.021 \\
\hline N-alkyl/Methoxyl C (\%) & Zone & 1 & 5.42 & 0.038 \\
\hline Carbohydrate C (\%) & Zone & 1 & 2.08 & 0.175 \\
\hline Di-O-alkyl C (\%) & Zone & 1 & 0.17 & 0.689 \\
\hline O-alkyl C (\%) & Zone & 1 & 0.01 & 0.916 \\
\hline $\mathrm{A} / \mathrm{O}$ ratio & Zone & 1 & 3.66 & 0.080 \\
\hline $\mathrm{A} / \mathrm{M}$ ratio & Zone & 1 & 8.05 & 0.015 \\
\hline
\end{tabular}

Note: * three sites in the warm temperate zone, and two sites in the sub-tropical zone. 


\section{Supplementary Fig. S1 Representative CP-MAS ${ }^{13} \mathrm{C}$ NMR spectra of different}

mineral soil horizon samples $(0-2,2-5$, and $5-10 \mathrm{~cm})$ at seven oriental oak sites. *, spinning sideband of carboxyl C (165-190 ppm).






Supplementary Fig. S2 Linear relationship between mean annual precipitation and oriental oak leaf delta ${ }^{13} \mathrm{C}$ along the gradient

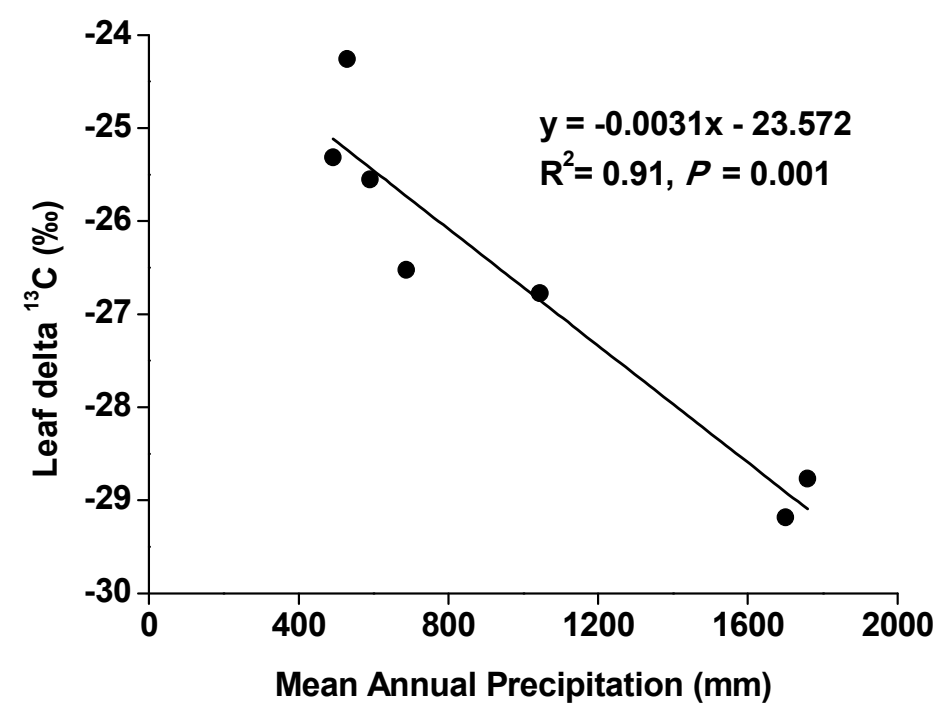

